\title{
Fanconi Anemia Group M Protein
}

National Cancer Institute

\section{Source}

National Cancer Institute. Fanconi Anemia Group M Protein. NCI Thesaurus. Code C54231.

Human fanconi anemia group M protein (2048 aa, $23 \mathrm{kDa}$ ) is encoded by the FANCM gene. This nuclear AT Pase is required for FANCD2 ubiquitination and is essential in DNA repair processes. 